\title{
Establishment of Vocational English Teaching System with Employment-oriented
}

\author{
Xiaoli Li \\ Chengdu Polytechnic, Chengdu 610041, China
}

Keywords: employment-oriented; higher vocational education; English teaching; teaching system; establishment

\begin{abstract}
This paper first summarizes the connotation and characteristics of vocational English teaching. It starts from three aspects: unclear talent training standard, monotonous course setting, and excessive hysteresis, which analyzes the existing problems of English teaching in vocational colleges. Moreover, the paper puts forward the optimized countermeasures for the construction of English teaching system based on employment. It is hoped that this paper will give some references to relevant fields.
\end{abstract}

\section{Introduction}

During the current social and economic cultural exchanges and comprehensive development, various vocational colleges need to reform the existing English teaching system in the education implementation. Meanwhile, we should fully integrate modern teaching concepts and social development requirements. At the present stage, most vocational colleges and universities start to cater to the needs of social development as the main body, and promote the optimization of English teaching content and ideas by constructing an employment-oriented English teaching system. We can operate several practical activities during the English teaching while training students' presentation skill. At the same time, we can use the practical activity to make clear of the student's own characteristic and the study demand then realize the teaching model consummation and reform. The construction of English teaching system in higher vocational colleges, which regards employment orientation as the main body, can be cultivated for students' ability. On the basis of satisfying the students' learning needs, the students can provide the conditions for the future employment development. In the following, this paper will elaborate and analyze the construction of vocational English teaching system based on the employment.

\section{Connotation and Characteristics of English Education in Vocational Colleges}

As the basic characteristic of vocational colleges, "professionalism" is also the main characteristic of the differences between higher vocational colleges and other colleges. During the rapid development of global economic integration, international exchanges have become increasing frequently. In this environment, it shows the importance of English, making English as the main part of the teaching content in higher vocational colleges. It plays a certain role in improving the development level and strengthening the core competitive power of students. However, from the current situation, the affected by the original teaching idea leads the focus on basic knowledge of English teaching. People pay more attention to writing rather than reading, which cannot meet the demand of society on the application. After entering into the 21st century, relevant departments of our country specified the content of English teaching standards in vocational English teaching. This is to ensure that students have adequate English knowledge and can cultivate their ability to listen, read and write. Through looking at a large number of materials, we can create a good atmosphere of English communication for students, laying a foundation for the future improvement of English communication [1]. In the process of teaching English teaching in higher vocational colleges, we should set up an English teaching system. On the basis of cultivating students' English application ability, the improvement of students' employment level will be promoted. 


\section{Existing Problems of English Teaching in Higher Vocational Colleges}

\subsection{The vague standard of talent cultivation.}

From the perspective of English teaching in higher vocational colleges, it focuses on the cultivation of students' future employability and practical ability. However, in terms of current situation, English teaching in higher vocational colleges is often confronted with the lack of clear objectives and the lack of practical teaching. In the process of setting up English curriculum, higher vocational colleges tend to focus on single teaching, which cannot meet the needs of current interdisciplinary talents. Most of the current higher vocational colleges in the process of teaching English, no practice teaching should be pay attention to, and can't take a combination of teaching content and language ability. Moreover, it cannot achieve comprehensive skill development.

\subsection{Curriculum setting in a single way.}

For the influence of the original teaching idea, most vocational colleges are often too simple in the course of teaching English teaching. On one hand, there is no understanding and exploration of the current English teaching process and rules in higher vocational colleges. On the other hand, the study of students' learning needs and characteristics is not sufficient. Some colleges and universities only teach for the sake of teaching, attaching too much importance to the implementation of teaching tasks, and resulting in poor overall teaching effect. At present, most colleges and universities often do not connect with students' own majors in the setting of English teaching content. The majority of students who choose to study in higher vocational colleges are mainly thinking about their own future development, which will lay a certain foundation for their future development [2]. However, most students generally believe that English learning will not play an important role in the future development, so they will not give full attention to English learning, which will lead to a low level of teaching.

\subsection{The hysterical assessment method.}

In the present English teaching of higher vocational colleges in China, the assessment form is written. This is means, according to the teaching content, setting and teaching content related questions, teachers understand the students' learning situation for the time being. The assessment results are used as a voucher to evaluate students' learning quality and provide reference for their future employment. Because institutions attach too much importance to the study of English vocabulary and other contents, they ignore the essential role of English teaching. In this way, students are less motivated to learn and cannot apply their knowledge to future employment. The lag of the assessment method and the deviation of the compound type training standard in higher vocational colleges have resulted in the teaching dissatisfaction.

\section{Establishment Optimization of Vocational English Teaching System with Employment-oriented}

\subsection{Scientific setting standards for talent cultivation.}

With the gradual acceleration of global economic integration, the society gives full attention to English teaching about the gradual expansion of China's opening to the outside world. At the same time, a large number of jobs related to English majors are also added, and the demand for English professional staff is gradually increasing. In order to meet the requirement of social employment development, higher vocational colleges should learn English listening, speaking, reading, writing and translating in English teaching. English teaching changes to the cultivation of compound talents, which is to train a group of talents with sufficient knowledge, methods and social skills. Knowledge ability mainly means that students not only have a good understanding of basic English knowledge and content, but also have strong attainments in English expression, and have certain ability of oral expression in English. Method ability mainly refers to the cultivation of students' professional knowledge and skills. On the basis of the professional knowledge, it also has certain market research and writing ability, which can be the only one in the future job market and have good 
development space [3]. Social ability refers to the ability of relearning and innovation, which can be handled calmly in the face of problems, so as to realize its comprehensive development.

\subsection{Improve curriculum setting.}

At present, most vocational colleges generally focus on the teaching setting of professional curriculum, without giving full attention to English teaching. In fact, English is the basic basis for learning professional knowledge, and students' skills in listening, reading and writing will provide the conditions for their future development. Therefore, the scientific setting of teaching courses will play an important role in the improvement of students' professional level and the cultivation of comprehensive qualities. Therefore, it is extremely necessary to set the employment orientation as the core teaching course content setting. In the course of course setting, we should not only pay attention to the cultivation of students' basic knowledge and ability, but also pay attention to the cultivation of students' language application ability. The future employment orientation and ability of students should be regarded as the core center, the cultivation of students' English language communication competence as the main body, and the theoretical knowledge and practical learning should be fully integrated. In order to achieve the rationality of the curriculum setting, teachers can start from three points. Firstly, in the basic English knowledge and teaching template setting, we should adhere to the standard and advocate the teaching refining. There is a great difference between English knowledge and English majors in higher vocational colleges. Therefore, in order to improve students' employment chances, it is generally accepted that "double certificates" are used as the basis to prepare students' employment. Therefore, basic knowledge teaching in English should be based on "sufficient". Let students learn to use it as the core basis of English teaching, and pay attention to the implementation of training objectives. On the basis of training students to listen and write, then apply the knowledge learned. Through the learning of every little bit, students' can learn to use the effect. Secondly, when setting up the English template for job hunting and employment, we should uphold the "practical" standard and advocate the imitation teaching. In this teaching system, the application of language knowledge should be emphasized. The purpose is to cultivate students' knowledge of English. In the selection of teaching content, we need to apply for the job, enterprise culture and other content and pay attention to the cultivation of English communication ability in the current employment situation of students. Thirdly, in the process of setting up a professional English module, we should uphold the "useful" standard and advocate practical teaching. In this teaching system, the content of teaching should be fully integrated with students' learning, and the professional content of English teaching should be explored. When we set up the curriculum standard, the actual scene and the need of employment are generally regarded as vouchers, which is mainly used to train the students' professional competence, so as to be able to use the language in the work. We need to build an English curriculum that will foster students' professional competence and enhance students' professional quality to meet the current needs of vocational education.

\subsection{Adopt modern assessment methods.}

At first, we should build a perfect assessment mechanism. In order to carry out the reform of English teaching in higher vocational colleges, we should pay attention to the cultivation of talents for the social and economic development. Examination as the teaching quality evaluation for English teaching should ensure that personnel training efficiency and level, which will fully demonstrate the scientific professional cultivation standards to evaluate mechanism. In the second place, it focuses on the integration of formative assessment and summary evaluation. At present, the assessment methods used in higher vocational colleges in China are lack of rationality and imperfect assessment mechanism. The assessment of students' learning situation is generally aimed at neutralizing the final exam results, and the assessment criteria are too monotonous. In order to realize the cultivation of English compound talents in higher vocational colleges, we should make a change in the form of examination. We need to adhere to the concept of formative assessment and summary and evaluation, and adopt diversified assessment methods. Moreover, we need to add process assessment method, weigh the proportion of assessment, so as to prevent the occurrence of 
"one paper fixed life" situation. Finally, the optimization evaluation content. When setting up the assessment content, the knowledge system should be changed. The teaching standards of education in higher vocational colleges directly affect the assessment content [4]. Therefore, in the process of English assessment, we should pay attention to the integration of theoretical knowledge and practical content, and the combination of knowledge assessment and skill assessment. Moreover, we should strengthen the assessment of the oral and listening ability, and should pay attention to the selection of the listening examination content in the listening assessment, so as to highlight its practicability.

\section{Summary}

Generally speaking, as vital to people's livelihood, employment and the employment guide as a voucher system of higher vocational college English teaching, can cultivate a large number of talents to the society, in order to meet the demand of choose and employ persons. It can effectively improve students' professional quality by carrying out English teaching in vocational colleges. It can cultivate students' good spirit and practice ability of employment. It can ensure that students can work after graduation. At the same time, it can also provide talent guarantee system construction to the social and economic development of our country and society.

\section{References}

[1] Li Bo. Modularized Vocational English Teaching System with Employment-oriented [J]. English on Campus, 2017(46):56.

[2] Qian Jiafu. Initial Exploration of Employment-oriented Vocational English Teaching System-take Yunnan Vocational Institute of Energy Technology for Example [J]. Course Education Research, 2017(28):116.

[3] Liu Hui. Discussion on Modularized Vocational English Teaching System with Employment-oriented [J] Education Modernization, 2016, 3(31):222-224.

[4] Cai Xiaoling. Construction Research of Employment-oriented Professional Practice Teaching System of Business English [J]. Contemporary Education Research and Teaching Practice, 2015(11):120.

[5] Guo Liya. On the Countermeasures of Strengthening Education and Management of Colleges Student Party Members [J]. English on Campus, 2015(01):62.

[6] Ma Qiuli. Research on the Employment-Oriented Practical Training System in Business English in High Vocational Colleges in Henan Province [J]. Journal of Henan Mechanical and Electrical Engineering College, 2014, 22(02):73-75. 